\title{
A VALUE-ORIENTED POLYPARADIGMAL APPROACH TO THE DEVELOPMENT OF MANAGEMENT EDUCATION IN THE CONDITIONS OF TRANSFORMATION CHANGE
}

\author{
Liudmila Batchenko', Maryna Dielini², Liliia Honchar ${ }^{3}$
}

\begin{abstract}
The purpose of the article is a theoretical, methodological, and practical justification for the introduction of a value-oriented polyparadigmatic approach to the development of management education. Methodology. Scientific analysis is carried out by an interdisciplinary system of methods: systemic philosophical analysis, structural functional method, generalization, modeling, and others. Results. The known methodological approaches to the formation of modern educational models of management training are considered; the essential concepts of educational paradigms are revealed and the necessity of their generalization is scientifically confirmed; the presence of values in each of them is established, which allowed to justify the polyparadigmatic approach to the development of management education. The most significant scientific results: the author's definition of the concept "value-oriented polyparadigmatic approach" is proposed, which is based on the understanding of the need to integrate effective educational paradigms based on the correlation of their valuable component in the educational construct of polyparadigmatic approach to management personnel development; principles of valueoriented approach to management activity (the principle of cognitive integrity; methodology; national orientation; axiological mediation; feasibility; polysubjectivity; the principle of statehood; scientific) is defined, the effectiveness of which ensures the complexity of their use at any level of management; axiological functions of the modern education system (ecological, humanistic, cultural heritage, creative, developmental, adaptive) are substantiated, which include certain axiological attitudes, affect the value aspects of training and education of the future manager and are important for the educational system, society, state, individual people in the present and will remain relevant for the future; a matrix of valuable orientations of the subjects of managerial activity is formed, which, according to the functional approach, has generalized the key parameters of determining the bank of competencies of managers. The practical significance of the study is in expanding and supplementing the theoretical and applied knowledge of management; in the possibility to apply knowledge in the educational process in the implementation of a value-oriented polyparadigmatic approach to management education; in use in the preparation of new regulatory and methodological documents on higher management education. Value/originality. The originality of the scientific research is represented by a fundamentally new combination (set) of methodological tools that ensure the uniqueness and value of scientific research.
\end{abstract}

Key words: axiology, value-oriented approach, methodological approach, paradigm, polyparadigmatic approach, manager, managerial education.

JEL Classification: A22, B41, 121, M53

\section{Introduction}

The relevance of the study is due to a number of objective circumstances, among which the following are of particular importance: the urgent need for

\footnotetext{
Corresponding author:

${ }^{1}$ Kyiv National University of Culture and Arts, Ukraine.

E-mail: ludavic@meta.ua

ORCID: https://orcid.org/0000-0001-6975-5813

${ }^{2}$ National University of Life and Environmental Sciences of Ukraine, Ukraine.

E-mail: marina.dielini@gmail.com

ORCID: https://orcid.org/0000-0003-1016-2305

ResearcherID: http://www.researcherid.com/rid/AAP-2566-2020

${ }^{3}$ Kyiv National University of Culture and Arts, Ukraine.

E-mail: glo1991@bigmir.net

ORCID: https://orcid.org/0000-0001-5621-0910
}

a systemic view of modern management education in the transformation of socio-economic relations, radical changes in all areas, affecting the state and development of higher education in general and management in 
particular. Scientific interest in the study of axiological issues is caused by transformational social changes, which, on the one hand, have led to changes in traditional values that have been focused on the education system, and on the other hand, have given rise to new values. This problem has prompted the scientific community to expand and improve value-oriented approaches for the further development of management education. The urgency of this theoretical and applied problem requires the subjects of educational activities, firstly, filling educational paradigms with new axiological (valuable) content of management training, and secondly, finding and developing a mechanism for adapting scientifically proven methodological approaches and principles to the preparation of management personnel, updating them taking into account valuable (axiological) guidelines.

The purpose of the study is to identify the main paradigmatic axiological characteristics of management education; to establish the degree of their possible correlation taking into account transformational changes; to substantiate the introduction of a value-oriented polyparadigmatic approach to the development of management education in the conditions of transformational changes.

The most significant scientific results:

- the author's definition of the concept "value-oriented polyparadigmatic approach" is proposed, which is based on the understanding of the need to integrate effective educational paradigms based on the correlation of their valuable component in the educational construct of polyparadigmatic approach to management personnel development;

- the principles of value-oriented approach to management activity (the principle of cognitive integrity; methodology; national orientation; axiological mediation; feasibility; polysubjectivity; the principle of statehood; scientific) are defined, the effectiveness of which ensures the complexity of their use at any level of management;

- the axiological functions of the modern education system (ecological, humanistic, cultural heritage, creative, developmental, adaptive) are justified, which include certain axiological attitudes, affect the value aspects of training and education of the future manager and are important for the educational system, society, state, individuals in the present and will remain relevant for the future;

- a matrix of valuable orientations of the subjects of managerial activity is formed, which, according to the functional approach, has generalized the key parameters of determining the bank of competencies of managers.

Based on the nature of the study, methods of various sciences were used, such as philosophy (dialectical, formal logical, systemic philosophical analysis, critical, modeling); culturology (psychological, structural and functional, modeling); sociology (information analysis, sociological observation, expert assessment); history (historical comparative, historical systemic, generalization). Each method has a certain potential and certain limitations when using in the study of the valuable component of methodological approaches and, on their basis, the existing educational paradigms of management personnel training. This comprehensive methodological approach to the subject of the study allowed to comprehensively analyze the problem of identifying current unresolved aspects of management training, defining the principles of value-oriented approach and axiological functions of the modern education system.

The following approaches have been identified and studied as a special methodology: civilizational, axiological (valuable), culturological, sociocultural, competence, humanistic, praxeological, systemicactivity, and practice-oriented.

According to the logic of presenting the material in the content structure of the article, the results of the study are structured in four sections: Axiological (valuable) direction of managers' education - Scientific and methodological provisions and approaches to managers' education - Problem field as an indicator of transformational changes in training systems formation of an educational model for the training of management specialists. Based on the results of the research, conclusions are formulated and problems for further scientific research are identified.

\section{Axiological (valuable) direction for training managers}

The study of axiology has always been important, but this problem has become especially relevant in the 21 st century due to changes in structures of values. In the second half of the 19th century in the system of production management attention to social and sociocultural parameters was relatively weak. Axiology has not yet penetrated into the field of labor organization and management, dominated by the principle of profit maximization through the minimization of labor costs. The tendency to form new meaningful concepts of value is based on the existence of a system of axiological knowledge, giving it a multidimensional and polyparadigmatic character.

The term "axiology" was introduced in 1902 by the French philosopher P. Lapi (Krainikova, 2017). Axiology as a philosophical discipline explores the nature of values, their place in reality, the structure of the value world, the conditionality of social and cultural factors. Axiology of education helped to create scientifically sound models of modern education, to predict trends in its development. In the second half of the 1980s, the general features of pedagogical axiology began to form (Rozin, 1989; Shchedrovitskii, 1993). 
Pedagogical axiology as an interdisciplinary field of knowledge considers education, training, upbringing, pedagogical activity in the vector of basic human values. Axiological priorities of strategic development of education are revealed by M.V. Bohuslavskyi (1999), Z.I. Ravkin (1995), N.D. Nikandrov (1998).

In its most consistent and systematic form, the philosophy of value was formed by Immanuel Kant (2000), the founder of German classical philosophy, who formulated his famous questions: "What can I know?", "What can I do?" and "What can I hope for?". Answers to them value a person, help to realize goals, ideals, hopes.

Values are quite diverse and create a complex system. Each historical epoch and each ethnic group had its own hierarchy of values, which determined socially acceptable behavior.

Many researchers, including Ukrainian sociologists and culturologists, have been engaged in the typology of values: O.G. Drobnitckii (1966), A.H. Maslow (1995, 1999), H. Rickert (1998), M. Rokeach (2015), V.P. Tugarinov (1968), A.Ya. Flier (2016), V.A. Yadov (1977).

The evolution of society's values takes place constantly, changing priorities and hierarchy, devaluing some and putting forward others. Studies of sociologists, psychologists, and culturologists are devoted to the problem of value orientations - B.G. Ananev (1968), E.I. Eroshenkova (2016), and N.I. Lapin (2000), D.A. Leontev (1996, 2002), V.S. Mukhina (2005), N.V. Sharkovskaia (2008), etc.

Value orientations also do not have an unambiguous interpretation and are considered by researchers as conscious beliefs and ideas of the subject about the value for him.

The relationship between "values" and "value orientations" is fixed as a problem of difference between declared and real values (D.A. Leontev, 1996).

Thus, the category "value" is an interdisciplinary category. Currently, based on a theoretical analysis of the category, there are more than 400 definitions of "value" from the point of view of different philosophical, sociological and psychological scientific schools, but they do not contradict each other. "Value" refers to general scientific concepts, the methodological significance of which is special for the process of training of managers.

Analyzing the definition of value according to their essential content, it should be noted that the unifying, integrative factor of numerous value variations is education, which in itself is a value in the philosophical and methodological sense.

Positive changes in society are possible only when education focuses on the formation of values.

The formation of value orientations is a rather complex process that changes over time and does not tolerate the directives of "imposition", but provides a delicacy in consolidating the value orientation of higher education seekers.

For management education, values are seen as the "core" of culture and education. Cultural aspects are related to the content and process of preparation of this profile of the specialist through the coincidence of the main functions of culture and education - the preservation and transmission of society's self-identity. There is a content-functional connection, which should become the basis of education of specialists in the modern world and will determine the main directions of the future educational process.

The problem of the system of value orientations in education is especially relevant in the transitional periods of social development (V.I. Ginetcinskii, 1989; Z.I. Ravkin, 1995; V.S. Sobkin, 2004).

The traditional system of management education, which focuses on training specialists with a set of professional competencies, no longer meets the requirements of modern business and society. Modernization of vocational education is also related to the issues of axiological training of managerial staff.

The most general approaches to the study of value orientations are described in the scientific literature. An important area of modern research is the study and evaluation of value priorities of future managers, modeling the system of their training taking into account the new value-oriented parameter.

A comprehensive analysis of the value category allowed us to consider the axiological approach to the education system in the context of transformational changes in modern society. Axiology, along with the theory of culture, psychology, pedagogy, has always been and will be the "ideological basis" for the education of future professionals. The educational potential of the educational activity of a higher education institution is a value basis for the formation of general professional competencies of applicants for higher education. Despite the different formulations of the concept of value, scientists agree that human activity has axiological properties.

In the new system of values, the priority should be the increase of human capital, the humanization of the economy, the inseparability and interdependence of economic and humanitarian development, effective international dialogue for peace and the achievement of sustainable development goals.

\section{Scientific and methodological provisions and approaches to the training of managers}

The procedural side of training activities is connected and disclosed through the methodological apparatus of the study (principles, functions, methods and approaches).

Among the basic principles there are the following: - principles of integrativeness and interdisciplinarity; 
- principles of regionalization and internationalization, which will help to harmonize and adapt the parameters of domestic and foreign education, ensure student mobility and the possibility of forming communicative competence;

- the principle of professional self-determination and autonomy, which confirms the openness, interaction of the training system with the business environment;

- the principle of openness (transparency) of learning objectives, content and evaluation criteria and ensuring a high level of personal responsibility of the student for the results of work;

- the principle of continuity, multilevel educational process, which requires the creation of criteria for assessing the formation of competencies at each level of education in accordance with the national and international qualifications framework.

In the process of training of future managers, it is necessary to take into account the interests of business and culture in management through the adequate formation of the functionality of future managers.

In the process of performing professional duties, the manager performs a number of functions: organizational and managerial, design and technological, communication, marketing, financial and economic, legal and others. When researching the problem of training future managers and developing an improved approach to the training model, it is necessary to take into account the functionality of future managers to determine their competencies.

Thus, the set of future professional competencies must fully correspond to the functional areas of managers. These requirements should be reflected in educational programs, curricula, as well as in forms, methods and modern learning technologies.

There is no unambiguous definition of professional competencies of graduates of Higher Education Institution (HEI) in the scientific literature. The concept of professional competence is associated with the production functions that are provided in the professional activity. Their design requires joint interaction of HEI, business, society, and the state.

There is no universal recipe for forming a model of professional competencies. Competences are not once and for all defined neoplasms, they are in constant development and renewal. Competence approach is a "method of modeling and designing educational outcomes" (Baidenko, 2004).

Multifunctional, interdisciplinary and transdisciplinary competencies create basic competencies - general scientific, socio-economic, civil law, informational and communicative, general professional (Zeer, Zavodchikov, 2007). Universal competencies (in Western terminology, soft-skills) are mental and interpersonal competencies that, unlike hard skills, cannot be quantified or certified. They are crosscutting and not subject-specific. They are subjective and poorly measured. The digital transformation of the economy and the technological revolutions of today are challenges and at the same time the need to master another group of skills - digital skills. These groups of skills should become separate puzzles in the design of the educational process and the appropriate basis for the formation of educational programs.

This approach of business to the required competencies of management professionals should be taken into account by HEIs in a paradigmatic approach to the formation of an educational model for the training of management professionals.

The educational model of the manager should take into account the existing methodological approaches: competence, humanistic, sociocultural, culturological, axiological (valuable), civilizational, praxeological, systemic-activity, and practice-oriented.

The competency approach has been adopted as one of the key methodological tools for modernizing vocational education in the European countries. Designing educational programs according to the competency approach means reflecting the results of education in a systemic and holistic way.

Competence approach is substantiated in the works of O.A. Gurianova (2009), I.A. Zimniaia (2006), A.V. Khutorskoi (2002).

The competency approach should be balanced by strengthening humanization in the educational activities of HEI.

Humanisticapproachineducation (S.U.Honcharenko, 2001; Yu. V. Senko, 2002). Humanization of education is a reorientation of education from the subject-content principle of learning to understand the valuable picture of the world and, above all, the world of culture, human, to the formation the humanities and systems thinking by managers. Yu.V. Senko (2002) emphasizes that humanitarian knowledge is not a priori. They become (or do not become) for those who master them. It all depends on whether the applicant sees personal meaning in them.

One of the most important practical directions of humanization is the meaningful transformation of syllabuses (work programs) of disciplines, so that they reflect the humanitarian nature of the student and the criteria for the humanitarian dimension of his personality.

The socio-cultural approach holds significant opportunities for the implementation of essential requirements for the education system of the 21 st century. It envisages combining the content of education and upbringing of young people into a holistic educational process based on a single goal, common socio-cultural values and technologies of effective learning. It ensures the harmonious development of the student's personality. It develops education as an open organizational system that can be an important unifying factor. 
Socio-cultural approach was formed over a long period. Pitirim Sorokin (2017), one of the classics of sociology of the 20th century, is rightly considered the founder of the socio-cultural approach. In the fundamental work "Social and Cultural Dynamics" he made a revolution in the theory of sociology, subordinating it to values as the main driving force of society.

One of the most important beliefs of P. Sorokin (1992) is expressed in his thesis "personality, society and culture as an inseparable triad" (p. 218).

In the formation of a modern understanding of the subject and essence of the socio-cultural approach contributed American sociologist T. Parsons (2002), American culturologist L. White (2004), and American sociologist R. Merton (1992).

Regarding the genesis of the development of the socio-cultural approach in Ukraine, we can single out the works of L. Batchenko (2018), L. Honchar (2018), J. Martynyshyn (2017), V. Rusavska (2018), O. Shcherbyna-Yakovleva (2017), etc.

The culturological approach is the main method of designing of personality-oriented education.

The culturological approach in education is a methodological orientation, which in its philosophical basis has an axiological (valuable) vector of development, substantiated in the works of M. Berdiaev (1993), A.N. Leontev (1996, 2005), P. Sorokin (2017).

The axiological approach is one of the important directions in solving the problems of humanistic training. This approach basically considers the concept of value as a scientific phenomenon, which has the following properties: activity-related and subjective; time variable; determines the properties of personality and has different meanings for them. The contribution to the development of the axiological approach was made by M.S. Kagan (1997), A.V. Kiriakova (2011), D.A. Leontev (2002), and others.

The civilization approach (A. Toynbee, 2004; G.B. Kornetov, 2001; S. Kopylova, 2019) as an opportunity to analyze the methodological potential in a specific historical framework allows us to present microresearch and its subjects included in the life of larger entities (culture, civilization, state, world economy). This approach enhances the formation of civic consciousness, corresponding to the challenges of civilization faced by society, education, and science. It is not possible to form civic positions fully outside the civilizational context.

The praxeological approach. The managerial function is praxeological by its nature. This approach allows to optimize the quality assessment of management training and develop relevant to a modern competent educational model of a specialist manager. General ideas of praxeology are reflected in psychology (Leontev, 2005); in pedagogy (Kolesnikova, Titova, 2005); in management (Bohoiavlenska, 2004); in education (Baidenko, 2004).
In the conditions of necessary interaction in the educational process of HEI with real business, the methodological component of professional training and adaptation of future managers should become systemicactivity and practice-oriented approaches.

The systemic-activity approach to learning is based on the theory of activity of A.N. Leontev (2005), which is based on the psychological concept of personality. This was a new vision of the problem of activity from the standpoint of psychological thought.

The very concept of systemic-activity approach was introduced in 1985, when systemic and activity approaches were combined (Ananev, 1968; Davydov, 1996).

The systemic-activity approach provides:

- formation of readiness for self-development and continuing education;

- designing the social environment of development (connection with society) in the education system;

- active educational and cognitive activity;

- construction of the educational process taking into account individual characteristics.

The famous report of the President of the International Commission on Education for the 21st Century Jacques Delors (1996) "Learning - Hidden Treasure", published by UNESCO in 1996, has not lost its relevance today.

In this report four pillars on which education is based were announced:

- learn to know;

- learn to do;

- learn to live together;

- learn to be.

These postulates have become decisive in the development and implementation of second-generation educational standards, which are based on a systemicactivity approach.

A relatively new form in the educational process is a practice-oriented approach to student learning (Bolotov, 1997; Borysenko, 2017; Serikov, 1999).

F.G. Yalalov (2008) most capaciously revealed the essence of the practice-oriented approach in the activitycompetence paradigm, according to which practiceoriented education is aimed at acquiring in addition to knowledge, skills, abilities - practical experience in order to achieve professional and socially significant competencies.

Practice-oriented approach should be crosscutting (conceptual) in the training of specialists. Tasks focused on the implementation of real business problems should be introduced from the very beginning of training, which will ensure the aggregation of the learning process and internships, as well as the formation of students' competencies that would ensure the performance of functional responsibilities in the speciality.

Considering methodological approaches will provide higher education not only practical, but also general 
cultural and social competencies that are necessary for their future professional activity.

\section{The problem field as an indicator of transformational changes in the training systems of rulers}

In a globalized world, problems are caused by transformations in the technical, informational, communicative fields due to the rapid acceleration of the pace of civilizational development.

In the field of management there have always been and will be problems as a result of transformation processes in economics, technology, science, which are directly correlated with the need to take them into account by the subjects of the educational process for further solution.

Such problems exist at all levels and can be divided into "global", "glocal" and "local". In general, these are problems of management, communications, infrastructure, legislation, finance and education.

Among the systemic consequences that will affect the situation in the educational sphere of Ukraine in accordance with the significant problems there are:

- marginalization of the socio-cultural sphere;

- unsatisfactory quality of the educational product;

- resistance to the external environment in the field of culture;

- mistrust between society and the authorities;

- non-promotion of culture as an important factor in the unification of society, its development;

- weak development of educational infrastructure;

- limited opportunities for the development of educational institutions;

- insufficient extra-budgetary sources of funding for education;

- the quality of management staff does not always meet modern requirements;

- the network of management institutions is not used in the educational process, which contradicts modern trends.

The identified "problem field" dictates the necessary system of competencies, functions and content of management, and hence sets the content of its training in the 21 st century.

Management of the 21 st century is a new paradigm of management, which is due to modern world trends, new economy, technological changes, changing knowledge for new professions, competencies, digitalization, development of e-business and the formation of business ecosystems and more. This order of world trends requires changes in the educational process of management training in the direction of expanding competencies and changing thinking - to systemicand value-oriented ones. Accordingly, the training of managers according to unified methods and standards is currently impossible.
The annual session of the World Economic Forum in Davos (2020) proclaimed the "Reskilling Revolution" - an initiative that aims to provide 1 billion people by 2030 better skills, education and jobs.

The key to training is better skills and better education.

When discussing issues of professional development and the future labor market, well-known experts (M. Zuckenberg, G. Soros, B. Gates and others) noted the rapid pace oflearning - the change of key professional skills, the reorientation of most future competencies to cognitive nature (related to thinking). Such statements of expert scientific opinion are a guideline for HEI to rethink the process of management training and develop adequate flexible educational models.

The model of a professional manager is a wide range of competencies that form the ability to apply knowledge in different situations (management, marketing, finance, economics, people management, etc.) and their deep (expert) level (functional knowledge and skills). A new key resource for management is leadership based on values, ethics, trust, creativity, and organizational culture.

In the Manifesto of the Leader (2013) G. Hamel notes that it is really important for the training of specialists now. These are ethical values, effective mechanisms of adaptation, enthusiasm for the future profession, constant involvement of students in the ideology of management. Today it is especially important to realize what degree of competence and responsibility lies on the modern manager.

Regarding the competence horizon 2020, the World Economic Forum (WEF, Davos, 2020) ranked among the most important and relevant: critical thinking, creativity, cognitive flexibility (ability to adapt), emotional intelligence, soft skills, customer orientation, initiative, creativity, enthusiasm. These skills of future professionals should be "nurtured" on every square meter of the university.

This is the purpose and mission of the university: the demand for graduates is the main task.

\section{Polyparadigmatic approach to the formation of an educational model of training management}

The era of mono-tools of learning is coming to an end; the popularity of poly-tool practices is growing.

The activities of managers became the subject of research in the field of socio-humanitarian sciences in the late 20th century. The works by H. Mintzberg (1991), I. Adizes (2018), M. Woodcock (1991), etc. are devoted to theoretical and practical aspects of managers' work. Their research sometimes does not always correspond to Ukrainian realities and cannot be fully implemented in national business practice. Recently, many works by domestic researchers have appeared, among which the works by L. Batchenko (2018), L. Honchar (2018), 
O. Hrishnova (2001), O. Kuzmin (2007, 2012), O. Melnyk (2007), O. Ovcharuk (2004), V. Rusavska (2018) and others should be singled out. However, the issues of value regulation of managers' activities remain insufficiently researched. The axiological side of the harmonization of the management process and, as a consequence, the system of management training is problematic today. The study of the possibilities of optimizing the educational training of managers from the standpoint of value-oriented approach is of great theoretical and practical importance.

Since, based on the abovementioned, management education is a complex, multidimensional educational and scientific object, which is studied from the standpoint of many sciences, so its conceptual representation (vision) should be based on a paradigmatic approach to its development.

The concept of paradigm was introduced into scientific circulation by the famous American scientist Thomas Kuhn (1977), who proposed as a conceptual module of science to take not a separate theory, but a set of theories that form a certain metatheoretical unity a paradigm based on different approaches and theoretical developments in scientific community. T. Kuhn (1977) identified various stages in the development of the paradigm as a scientific category:

- pre-paradigmatic (the future paradigm is in a state of formation, it has many opponents);

- paradigmatic (period of paradigm domination);

- post-paradigmatic (growing criticism of existing theory among scientists and administrative circles in science).

Thus, the paradigm is similar to living beings: it is born, it lives (reigns), and dies.

The scientific revolution according to T. Kuhn (1977) leads to a paradigm shift, the transition from one to another. That is, T. Kuhn (1977) was the first to talk about changing the paradigm. "By paradigm," writes T. Kuhn (1977), "I mean the scientific achievements recognized by everyone, which for some time give the scientific community a model of problems and their solutions." According to his general scientific definition, a paradigm is a set of theoretical and methodological attitudes, a concept broader than a theory, concept or approach. Several theories, concepts or approaches to a particular object of study may correspond to one paradigm.

As G. Hamel (2007), authoritative American author of "Management 2.0", chief management specialist and head of the Silicon Valley Management Lab, writes in his book "The Future of Management": "Paradigm is more than a way of thinking, it is a worldview, a deep conviction of what kind of problems should be solved and what can be solved in general".

Traditionally, the "paradigm" (paradeigma) is considered as a concept of methodology of science, but the multidimensionality, contradictions, constant variability of the modern educational environment necessitate the development of alternative concepts of educational practice and their methodological justification and design.

For education, the "paradigm" is an ascending conceptual scheme, model, solution to the problem in education (learning). The paradigm of education can be understood as a set of modern basic concepts and ideas that are recognized by the scientific and educational community and underlie further research in education.

Higher education opens up new horizons related to innovative technologies. This is an opportunity to accumulate huge amounts of new knowledge in the field of management, economics, communication and their rapid spread.

The paradigm of management education is formed also in the course of the development of management in general and the competence approach to the educational process in particular.

Since knowledge develops consistently and is based on its evolutionary development of succession, the development of new conceptual visions is based on probable concepts and is their generalization (Figure 1).

The polyparadigmatic approach takes into account the main value-oriented characteristics of paradigms. And also takes into consideration the dominant type of thinking in society in general and in business in particular, functionality, innovation, flexibility. The polyparadigmatic approach is a system of coordinates of the dominant views of the subjects of educational management training (standards, principles, models, rules) taking into account the requests of business structures. Approaches are not mutually exclusive, they are used together and complement each other, giving multi-vector and multifaceted management training system.

Of course, in the framework of the article, it is impossible to provide a detailed description of each educational paradigm defined by the research framework and the factors of their interaction. Therefore, conceptually we consider only the main paradigms, which, correlating with each other, give a synergistic effect, strengthening the competitiveness of training in management, and determine the meaningful direction of implementation in the educational process of polyparadigmatic approach.

The basis of such a conceptual vision is a kind of methodological construct, which in use will be appropriate only in the system of common values. Without a foundation of values, it will be just an eclectic design.

The competency paradigm and methodological approaches due to it have become a strategic direction in the development of professional management education at the present stage. The main goal of the competency paradigm is to form a competent specialist in the field of management in an organic combination of 


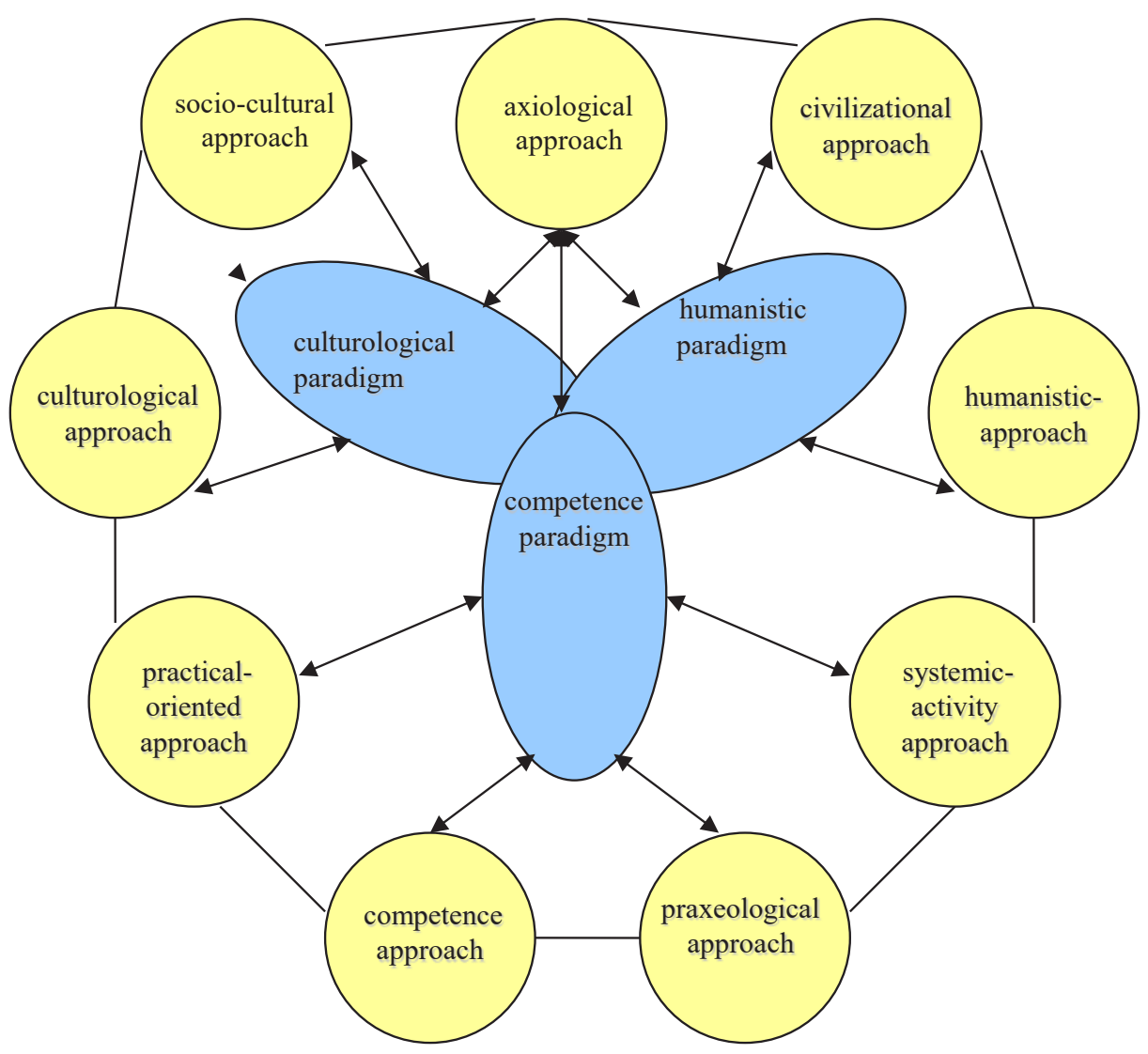

Figure 1. Polyparadigmatic conceptual approach to management training

complex cultural and professional competencies, based on students' acquisition of conscious knowledge, skills, methods of activity, self-education, self-bringing up, selfimprovement and self-realization. The abovementioned elements of the complex of competence paradigm are realized through the culturological and humanistic paradigm as well.

The humanistic paradigm comes down to the fact that education should shape the individuality of the specialist. Humanistic education will become a means of social orientation of the individual. The formation and development of the humanistic educational paradigm determine new theoretical directions and methodological approaches, methods of organizing the learning process for further management.

According to I. Sergeev (2004), certain elements of the humanistic paradigm have proved to be a strong catalyst for all modern educational reform and continue to retain their role as a "breath of fresh air" in pedagogical activities (p. 123).

The culturological paradigm approaches education as a sociocultural phenomenon. The problem of the relationship between culture and education is covered in the works of M. Bakhtin (1985), V. Bibler (1991), A. Bondarevskaia (2015).

In general, the cultural paradigm in terms of valueoriented polyparadigmatic approach to management training is implemented through the design of a matrix of value orientations of management entities (Figure 2), functional approach of which summarizes the key parameters of defining the bank of competencies of managers.

Each of the abovementioned paradigms is an independent equilibrium, they are still used in the training system to some extent depending on the free economic zone, speciality, training system. But, given that modern management education is not defined by a clearly formulated single paradigm of training managers, it is necessary to recognize the fact of polyparadigm.

T. Kuhn's (1977) conclusion that "no paradigm ever solves all problems" is still more relevant today than ever. But paradigms can complement each other while forming a value-oriented paradigm approach to the development of management education in a transformational change.

In recent years, a number of changes have been made in the system of training management specialists. The transformation is based on a new concept of higher education, which takes into account the rapid variability of the socio-cultural situation, new priorities in social development, new trends in business education. But the rapid variability of processes and systems makes constant adjustments to educational models of training. 


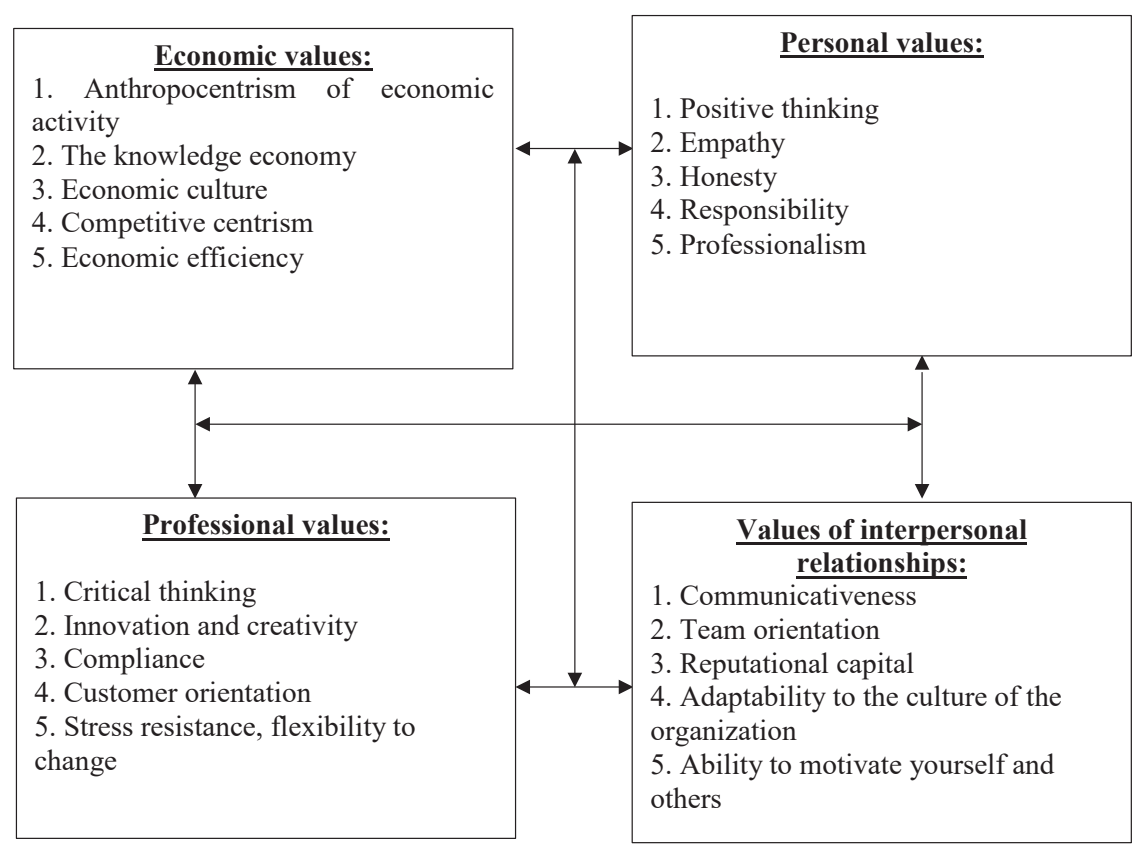

Figure 2. Matrix of value orientations of subjects of administrative activity

Procedurally in the design of training of managers qualitatively new parameters should be used that would ensure the implementation of innovative educational technologies through the creation of an effective mechanism for their implementation in the training process.

Guaranteeing quality management education in the 21 st century is possible only on the basis of the principle of polyparadigm: the integration of modern innovative educational systems of education and personal development in the training process. The polyparadigm of modern science and education is already a recognized fact. Changing scientific and educational paradigms in educational activities is necessary for further transformations.

The polyparadigmatic approach to the management education system provides an opportunity to analyze specific phenomena, situations, conditions comprehensively, which will serve as a certain indicator for choosing the necessary innovative flexible educational model, synthesizing the role of which will be in the value-oriented vector of management education.

\section{Conclusions}

The results of research, based on scientifically and methodologically sound basic provisions, basic principles and existing educational models of training, as well as on the analysis of the requirements for the training of managers, indicate that:

1. Conceptual view of the polyparadigmatic approach to the educational process of management training not only actualized the problem points of management development, but also justified their solution in the value-oriented vector of management education, which will prevent the lag of meaningful content of university management education (national and foreign).

2. Using the term "value-oriented polyparadigmatic approach" to the training of managers, we understand that its phenomenon is quite rare. In our understanding, the change of the existing paradigm of training managers is presented as the formation of a new understanding of some of its key parameters, i.e. certain paradigm changes that are necessary and dictated by time, market, business and can synergize on educational outcomes.

3. This polyparadigmatic conceptual vision requires concretization to the level of organizational and technological mechanism, which must be further implemented in the form of innovative scientific and methodological approaches to improve practical results in the educational process of training.

4. Implementation of the main provisions of the polyparadigmatic conceptual approach to the training of managerial staff will create a scientific and professional basis in the system of training management, which focuses on the formation of values, social activity, patriotism, civic position, cultural tolerance and more.

Prospects for further scientific exploration in this direction are primarily:

- theoretical and methodological substantiation of the development of educational models that would reflect the convergence of modern science and innovative technologies in the higher education system. 
- development of a single information space of scientific communication in the field of management;

- features of training of management specialists in accordance with the needs of regional labor markets;
- digitalization of the educational process - the use of informational educational technologies (digital technologies) during the full educational cycle of management training.

\section{References:}

Adizes, I. (2018). Insights on Management: vol. III. Available at: https://www.amazon.com/Insights-ManagementDr-Ichak-Adizes/dp/0937120405 (accessed June 20, 2020).

Ananev, B. G. (1968). Chelovek kak predmet poznaniia [Man as a subject of cognition]. Leningrad: Leningrad State University. (in Russian)

Bakhtin, M. K. (1985). Filosofiia postupka [Philosophy of action]. Philosophy and Sociology of Science and Technology. Moscow. (in Russian)

Baidenko, V. I. (2004). Kompetentcii v professionalnom obrazovanii (k osvoeniiu kompetentnogo podkhoda) [Competence in vocational education (to the development of a competent approach)]. Hanging education in Russia, no. 11, pp. 3-13. (in Russian)

Berdiaev, N. A. (1993). O naznachenii cheloveka [On the appointment of a person]. Moscow: Respublika. (in Russian)

Bibler, V. S. (1991). Ot naukoucheniia - k logike kultury: dva filosofskikh vvedeniia v dvadtcat pervyi vek [From Science Teaching - to the Logic of Culture: Two Philosophical Introductions to the Twenty-First Century]. Moscow: Izd. Polit. Literatury. (in Russian)

Bohoiavlenska, O. V. (2004). Prakseolohiia u systemakh suchasnoho menedzhmentu [Praxeology in modern management systems]. Scientific works of ONAZ named after O.S. Popova, no. 3, pp. 107-109. (in Ukrainian)

Bohuslavskyi, M. V. (1999). Struktura suchasnoho istoryko-pedahohichnoho znannia [The structure of modern historical and pedagogical knowledge]. The path of education, vol. 1, no. 11, pp. 37-40. (in Ukrainian)

Bolotov, V. A., Isaev, E. I., Slobodchikov, V. I., \& Shaidenko, N. A. (1997). Proektirovanie professionalnogo pedagogicheskogo obrazovaniia [Designing professional pedagogical education]. Pedagogy, no. 4, pp. 66-72. (in Russian)

Bondarevskaia, E. V. (2015). Gumanisticheskaia paradigma lichnostno-orientirovannoi obrazovatelnoi sredy [The humanistic paradigm of a personality-oriented educational environment]. Pedagogy, no. 4, pp. 11-17. (in Russian) Borysenko, V. (2017). Intehrovane navchannia: tematychnyi i diialnisnyi pidkhid [Integrated learning: thematic and activity approach]. Available at: https//mozaikaped.blogspot.com/2017/08/integrovanenavchannjatematychnyj-i-.html?view=flipcard (accessed June 15, 2020). (in Ukrainian)

Davydov, V.V. (1996). Teoriia razvivaiushchego obucheniia [Theory of developing learning]. Moscow. (in Russian)

Delors Jacques (1996). Obrazovanie - sokrytoe sokrovishche [Osnovnye polozheniia doklada ... dliia XXI veka] [Learning - hidden treasure [Report Highlights ... for the 21st Century]]. UNESCO. Available at: https://www.ifap.ru/library/book201.pdf (accessed June 15, 2020). (in Russian)

Drobnitckii, O. G. (1966), Nekotorye aspekty problemy tcennostei [Some aspects of the problem of values]. The problem of values in philosophy (chief ed. Kharchev A. G.). Moscow; Leningrad: Science, pp. 25-41. (in Russian) Eroshenkova, E. I. (2016). Aksiologicheskie orientiry obrazovatelnoi realnosti: ot istokov k sovremennosti professionalnogo obrazovaniia [Axiological guidelines of educational reality: from the origins to the modernity of vocational education]. Gaudeamus, no. 4, pp.9-14. (in Russian)

Flier, A. Ya. (2016). Sotciodinamika kultury: mnogoobrazie vozmozhnostei [Sociodynamics of culture: diversity of possibilities]. Culture of culture, no. 1. Available at: http://cult-cult.ru/sociodynamics-of-culture-a-variety-ofpossibilities/ (accessed July 20, 2020). (in Russian)

Hrishnova, O. (2001). Rozvytok vyshchoi osvity v Ukraini: tendentsii, problemy ta shliakhy yikh vyrishennia [Development of higher education in Ukraine: tendencies, problems and ways of their solution]. High school, no. 2-3, pp. 22-33. (in Ukrainian)

Ginetcinskii, V. I. (1989). Znanie kak kategoriia pedagogiki: Opyt pedagogicheskoi kognitologii [Knowledge as a category of pedagogy: The experience of pedagogical cognitology]. Leningrad, p. 87. (in Russian)

Honcharenko, S. U. (2001). Humanizatsiia osvity yak osnovnyi kryterii rozrobky zasobiv realizatsii suchasnykh tekhnolohii navchannia [Humanization of education as the main criterion of development of means of realization of modern technologies of training]. Science. zap. Ser.: Ped. Sciences / Institute of Teaching Aids of the Academy of Pedagogical Sciences of Ukraine, Kirovohrad. state ped. Univ. Vladimir Vinnichenko. Kirovograd, vol. 34: Means of realization of modern technologies of training, pp.3-8. (in Ukrainian)

Gurianova, O. A. (2009). Sotcialno-psikhologicheskoe soprovozhdenie formirovaniia professionalnoi kompetentnosti budushchego spetcialista [Socio-psychological support for the formation of professional competence of a future specialist]. Proceedings of the Tekhnologii formirovaniia professionalnoi kompetentnosti budushchego spetcialista: mezhregionalnaia nauchno-prakticheskaia konferentciia [Technologies for the formation of professional competence of a future specialist: interregional scientific and practical conference] (Russia, Orenburg, March 16, 2009) (ed. Sergeeva N. A.), Orenburg: OGPPK, pp. 33-39. (in Russian)

Hamel, G., \& Breen, B. (2007). The Future of Management. Boston, MA: Harvard Business School Press. 
Hamel, G. (2011). Menedzhment XXI veka: Novye otkrytiia [Century Management: New Discoveries]. Available at: https://gtmarket.ru/library/articles/4246 (accessed July 18, 2020). (in Russian)

Hamel, G. (2009). Menedzhment 2.0: Novaia versiia dlia novogo veka [Management 2.0: A New Version for the New Age]. Harvard Business Review. Russia, no. 10, pp. 91-100. (in Russian)

Issledovanie tcennostnyi orientatcii M. Rokeach (2015) [Values List of M. Rokeach]. PSYCHOJOURNAL.RU is a popular scientific psychological portal. Available at: https://psychojournal.ru/tests/479-issledovanie-cennostnyhorientaciy-m-rokicha.html (accessed August 20, 2020). (in Russian)

Kagan, M. S. (1997). Filosofskaia teoriia tcennostei [Philosophical theory of values]. St. Petersburg: TOO TK "Petropolis". (in Russian)

Kant, I. (2000). Krytyka chystoho rozumu [Critique of pure reason]. Filosofija: Khrestomatija [Philosophy: Reader]. Kamenets-Podolsky: Abetka, pp. 94-102. (in Ukrainian)

Khutorskoi, A. V. (2002). Kliuchevye kompetentcii i obrazovatelnye standarty [Key competencies and educational standards]. Internet magazine "Eydos". Available at: http://eidos.ru/journal/2002/0423 (accessed August 15, 2020). (in Russian)

Kiriakova, A. V. (2011). Tcennostnye orientiry universitetskogo obrazovaniia [Valuable landmarks of university education]. OSU Bulletin, no. 2, pp. 27-33. (in Russian)

Kolesnikova, I. A., \& Titova, V. E. (2005). Pedagogicheskaia prakseologiia [Pedagogical praxeology]. Moscow: Izd. Tsentr "Akazhemiya”. (in Russian)

Kopylova, S. (2019). Tsyvilizaysiini vyklyky XXI stolittia: modernizatsiia profesiinoii pidhotovky mahistriv sotsialnoi roboty [Civilization challenges of the XXI century: modernization of professional training of masters of social work]. Social Work and Education, vol. 6, no. 3. Ternopil-Aberdeen, pp. 296-306. DOI: 10.25128/25206230.19.3.7 (in Ukrainian)

Kornetov, G. B. (2001). Itogi i perspektivy paradigmalnopedagogicheskoi interpretatcii modelei obrazovatelnogo protcessa [Results and prospects of paradigmatic pedagogical interpretation of models of the educational process]. Humanitarian science, no. 1, p. 95. (in Russian)

Krainikova, T. S. (2017). Aksiolohiia [Axiology]. Velyka ukrainska entsyklopediia [Great Ukrainian encyclopedia]. Available at: https://vue.gov.ua/Аксіологія (accessed August 20, 2020). (in Ukrainian)

Kuhn, T. (1977). Struktura nauchnykh revoliutcii [The Structure of Scientific Revolutionary]. Moscow: Progress. (in Russian)

Kuzmin, O. Ye. (2012). Kontseptsiia ta evoliutsiia protsesno-strukturovanoho menedzhmentu [The concept and evolution of process-structured management]. Economics: the realities of time, no. 2(3), pp. 7-16. (in Ukrainian)

Kuzmin, O. Ye., \& Melnyk, O. H. (2007). Osnovy menedzhmentu [Fundamentals of management]. Kyiv: Akademvydav. (in Ukrainian)

Lapin, N. I. (2000). Sotciokulturnyi podkhod i sotcietalno-funktcionalnye struktury [Sociocultural approach and societal-functional structures]. Sociological Research, no. 7, pp. 3-12. (in Russian)

Leontev, A. N. (1996). Tcennost kak mezhdistciplinarnoe poniatie: opyt mnogomernoi rekonstruktcii [Value as an interdisciplinary concept: the experience of multidimensional reconstruction]. Questions of Philosophy, no. 4, p. 16. (in Russian)

Leontev, A. N. (2005). Deiatelnost. Soznanie. Lichnost [Activity. Consciousness. Personality]. Moscow: Smysl, Akademiya. (in Russian)

Leontev, D. A. (1996). Tcennost kak mezhdistciplinarnoe poniatie: opyt mnogomernoi rekonstruktcii [Value as an interdisciplinary concept: an experience of multidimensional reconstruction]. Questions of Philosophy, no. 4, pp. 15-26. (in Russian)

Leontev, D. A. (2002). Metodika izucheniia tcennostnyi orientatcii [Methods for studying value orientations]. Moscow. (in Russian)

Martynyshyn, Ya. M. (Ed.). (2017). Obhruntuvannia Paradyhmy Menedzhment-Osvity u Sotsiokulturnii Sferi [Substantiation of the Paradigm of Management Education in the Socio-Cultural Sphere]. Bila Tserkva: Pshonkivskyi O. V. (in Ukrainian)

Maslow, A. H. (1999). Psikhologiia bytiia [The Psychology of Being]. Saint-Petersburg. (in Russian)

Maslow, A., Fadiman, J., \& Frager, R. (1995). Abraham Maslow i psikhologiia samoaktualizatcii [Abraham Maslow and the psychology of self-actualization]. Khrestomatiia po gumanisticheskoi psikhoterapii [A reader for humanistic psychotherapy]. Moscow, pp. 111-150. (in Russian)

Merton, R. (1992). Sotcialnaia teoriia i sotcialnaia struktura. Sotcialnaia struktura i anomiia [Social theory and social structure. Social structure and anomia]. Sociological Research, no. 2-4. (in Russian)

Mintzberg, H. (1991). Strategic thinking as seeing. Nasi. Arenas of Strategic Thinking. Foundation of Economic Education. Helsinki.

Mukhina, V. S. (2005). Predislovie [Preface]. Mekhanizmy formirovaniia tcennostnykh orientatcii i sotcialnoi aktivnosti lichnosti [Mechanisms for the formation of value orientations and social activity of the individual]. Moscow: MGPI, pp. 4-7. (in Russian)

Nikandrov, N. D. (1998). Dukhovnye tcennosti i vospitanie cheloveka [Spiritual values and human education]. Pedagogy, no. 4. (in Russian) 
Ovcharuk, O. V. (Ed.) (2004). Kompetentnisnyi pidkhid u suchasnii osviti: svitovyi dosvid ta ukrainski perspektyvy: Biblioteka z osvitnoi polityky [Competence approach in modern education: world experience and Ukrainian perspectives: Library on educational policy]. Kyiv: “K. I. S.” (in Ukrainian)

Parsons, T. (2002). Poniatie kultury i sotcialnoi sistemy [The concept of culture and social system]. On social systems (eds. Chesnokova V. F., Belanovskii S. A.). Moscow: Academic Project, pp. 693-776. (in Russian)

Ravkin, Z. I. (1995). Konstruktivno-geneticheskoe issledovanie tcennostei obrazovaniia - odno iz napravlenii razvitiia sovremenoi otechestvennoi pedagogicheskoi teorii. Obrazovanie: idealy i tcennosti (istorikoteoreticheskii aspekt) [Constructive-genetic study of educational values is one of the directions of development of modern domestic pedagogical theory. Education: ideals and values (historical and theoretical aspect)]. Moscow: ITOiP RAO. (in Russian)

Rickert, H. (1998). Nauki o prirode i nauki o kulture [Nature Sciences and Cultural Sciences]. Moscow: Respublika. (in Russian)

Rozin, V. M. (1989). Spetcifika i formirovanie estestvennykh, tekhnicheskikh i gumanitarnykh nauk [Specificity and formation of natural, technical and humanitarian sciences]. Krasnoyarsk: Publishing house Krasnoyarsk. University. (in Russian)

Rusavska, V. A., Batchenko, L. V., \& Honchar, L. O. (2018). Problemni aspekty menedzhmentu ta menedzhmentosvity $\mathrm{v}$ umovakh rynkovykh zmin [Problem aspects of management and education management in conditions of market change]. Bulletin of Kyiv National University of Culture and Arts. Series in Management of Social and Cultural Activity, no. 1, pp. 78-97. doi: 10.31866/2616-7573.1.2018.143391 (in Ukrainian)

Sergeev, I. S. (2004). Osnovy pedagogicheskoi deiatelnosti [Fundamentals of pedagogical activity]. St. Petersburg: Piter. (in Russian)

Senko, Yu. V. (2002). Pedagogicheskii protcess kak gumanitarnyi fenomen [Pedagogical process as a humanitarian phenomenon]. Pedagogy, no. 1, pp. 14-15. (in Russian)

Serikov, V.V. (1999). Obrazovanie i lichnost. Teoriia i praktika proektirovaniia pedagogicheskikh sistem [Education and personality. Theory and practice of designing pedagogical systems]. Moscow. (in Russian)

Sharkovskaia, N. V. (2008). Sotciokulturnye instituty - deiatelnostnaia osnova sotciokulturnoi aktivnosti lichnsoti [Sociocultural institutions - the activity basis of the sociocultural activity of the individual]. MGUKI Bulletin, no. 4, pp. 149-152. (in Russian)

Shchedrovitskii, G. P. (1993). Sistema pedagogicheskikh issledovanii (Metodologicheskii analiz) [The system of pedagogical research (Methodological analysis) ]. Pedagogy and Logic. Moscow: Kastal, pp. 16-201. (in Russian)

Shcherbyna-Yakovleva, O. (2017). Poniattia Sotsiokulturnoi Diialnosti: Filosofski ta Kulturolohichni Vymiry [The Concept of Socio-Cultural Activities: Philosophical and Culturological Dimensions]. Worldview - PhilosophyReligion, no. 12, pp. 71-78. (in Ukrainian)

Sobkin, V. S., Abrosimova, Z. B., Adamchuk, D. V., \& Baranova, E. V. (2004). Proiavleniia deviatcii v podrostkovoi subkulture [Manifestations of deviation in adolescent subculture]. Psychological issues, no. 3, pp. 3-18. (in Russian) Sorokin, P. A. (2017). Sotcialnaia i kulturnaia dinamika [Social and cultural dynamics]. Moscow: Akademicheskii proekt. (in Russian)

Sorokin, P. A. (1992). Chelovek. Tcivilizatciia. Obshchestvo [Man. Civilization. Society]. Moscow: Politizdat. (in Russian)

Toynbee, A. J. (2004). Postizhenie istorii [A Study of History]. Moscow: Ayris-press. (in Russian)

Tugarinov, V. P. (1968). O tcennostiakh zhizni i kultury [On the values of life and culture]. Leningrad: Leningrad State University. (in Russian)

White, L. (2004). Izbrannoe. Nauka o culture [Favorites. The science of culture]. Moscow: ROSSPEN. (in Russian) Woodcock, M., \& Francis, D. (1991). Raskreposhchennyi menedzher: dlia rukovoditelia-praktika [The Unblocked Manager: A Practical Guide to Self-Development] (Trans. in Eng.). Moscow: Delo. (in Russian)

World Economic Forum in Davos (2020). Pidsumky 50-oi Yuvileinoi Zustrichi [Results of the 50th Anniversary Meeting]. Available at: https://www.rbc.ua/static/longread/davos_ukr/index.html (accessed March 20, 2020). (in Ukrainian)

Yadov, V. A. (1977). Lichnost kak obekt i subekt sotcialnykh otnoshenii [Personality as an object and subject of social relations]. Sociology and modernity, p. 385. (in Russian)

Yalalov, F. (2008). Deiateklnostno-kompetentnostnyi podkhod k praktikoorientirovannomu obrazovaniiu [Activity-competence approach to practice-oriented education]. Higher education in Russia, no. 1, pp. 89-93. (in Russian)

Zimniaia, I. A. (2006). Kliuchevye kompetentcii - novaia paradigma rezultata obrazovaniia [Key competencies a new paradigm of the result of education]. Internet magazine "Eydos". Available at: http://www.eidos.ru (accessed July 15, 2020). (in Russian)

Zeer, E., \& Zavodchikov, D. (2007). Identifikatciia universalnykh kompetentcii vypusknikov rabotodatelem [Identification of universal competencies of graduates by the employer]. Higher education in Russia, no. 11, pp. 39-45. (in Russian) 